FACTA UNIVERSITATIS

Series: Physical Education and Sport, Vol. 18, No 3, 2020, pp. 589 - 600

https://doi.org/10.22190/FUPES191008057V

Research article

\title{
RELATIONSHIP BETWEEN BASIC PERSONALITY DIMENSIONS AND DISPOSITIONAL COPING STRATEGIES IN VOLLEYBALL
}

UDC 796. 071.325:159-924.2

\begin{abstract}
Ana Vesković, Ana Orlić, Goran Nešić
Faculty of Sport and Physical Education, University of Belgrade, Belgrade, Serbia
\end{abstract}

\begin{abstract}
Athletes' coping strategies are important factors that contribute to competitive achievement and psychological well-being. The first aim of the current study was to explore the direct and interactive effects of Five Factor personality dimensions on dispositional coping strategies. The second aim was to test the second-order factorial structure of the Dispositional Coping Inventory for Competitive Sport (DCICS). The sample included 166 female volleyball players of mean age 15.01 years $(S D=.87)$, and mean sports experience of 4.81 years $(S D=1.85)$. They completed the NEO-FFI inventory and DCICS. Explorative factor analyses indicated two second order solutions with high reliability coefficients: task-and emotion-oriented coping strategies. The Paired samples $t$-test showed that young female athletes more often apply task-oriented strategies than emotion-oriented strategies. The regression analysis showed that some Five-Factor personality dimensions independently predicted the use of higher order coping dimensions. Conscientiousness was the only positive predictor of task-oriented strategies. Neuroticism was positive and agreeableness is a negative predictor of emotion-oriented coping strategies. No interaction effects of personality dimensions on dispositional coping were founded. These findings suggest that the Five-Factor personality model can predict the coping strategies that athletes frequently use. Findings also emphasize the need for more studies aimed to investigate this complex relationship including potential moderator effects of different variables such as gender, sport experience, competitive achievement, and different sports disciplines.
\end{abstract}

Key words: Personality Traits, Coping Strategies, Athletes

Received October 08, 2019/ Accepted December 25, 2020

Corresponding author: Goran Nešić

Faculty of Sport and Physical Education, University of Belgrade, Blagoja Parovića 156, 11000 Belgrade, Serbia

Phone: + 381113531000 •E-mail: goran.nesic@fsfv.bg.ac.rs

(C) 2020 by University of Niš, Serbia | Creative Commons License: CC BY-NC-ND 


\section{INTRODUCTION}

Sports competitions can be a significant source of stress, and stresses that athletes experience during a competition are often intense (Kimball \& Freysinger, 2003). Therefore, it is not surprising that in the last 30 years there is a growing number of studies that focused on stress among athletes. Competitive stress refers to the ongoing transaction between an individual and the demands of the environment related particularly and in direct way to competitive performance (Fletcher, Hanton, \& Mellalieu, 2006: 7). There are two different lines in studying competitive stress: within the first, the main interest is the athletes` perception of the sources of the competitive stress (i.e., stressors), and within the second, the authors focused on athletes` cognitions, emotions and coping strategies (Abedalhafiz, Altahayneh, \& Al-Haliq, 2010).

Coping strategies are considered to be one of the key processes that can develop selfregulation and involve willing thoughts and activities by which athletes control the physical and psychological demands of the situation (Skinner \& Zimmer-Gembeck, 2007). Coping can be assessed at the situation level or the personal, dispositional level (Hurst, Thompson, Visek, Fisher, \& Gaudreau, 2011). Within the situational level, coping is defined as the actual or momentary utilization of coping strategies in a particular situation. Within the dispositional approach, individual differences in stable coping strategies are in focus (i.e., dispositions). Dispositions are high predictors of athletes reactions, and they are stable during long periods of time (Louvet, Gaudreau, Menaut, Genty, \& Deneuve 2007).

Whether or not coping strategies are assessed as a process or disposition, there are many types of coping strategies that are classified in different ways: on the micro-analytical and macro-analytical level. The micro-analytical level of classification implies the identification of specific types of coping strategies, for example, seeking social support, imagery, resignation, relaxation (Gaudreau \& Blondin, 2004), planning, suppression of competing activities, seeking social support for emotional reasons, humor, denial (Crocker \& Graham, 1995). The macro-analytical level of classification implies grouping similar coping strategies into higher-order coping dimensions (Crocker, Tamminen, \& Gaudreau, 2015).

Although some authors consider that the classification of specific types of higher-order coping dimensions can mask their diversity and complexity (Compas, Connor-Smith, Saltzman, Harding Thomsen, \& Wadsworth, 2001), other authors claim that such classifications are useful because they give a deeper understanding of the usual reactions to competitive stress (Nicholls \& Polman, 2007). According to one often referred to classification of coping strategies, strategies are classified into three higher-order dimensions (Nicholls \& Polman, 2007): problem-focused coping strategies (useful for minimizing distress by reducing and eliminating factors that produce the stress), emotionfocused coping strategies (useful for optimising emotional arousal and distress), and avoidance coping strategies (behavioural and psychological efforts to avoid stressful situations). Since specific requirements of sport require specific types of coping strategies (Kowalski \& Crocker, 2001), some of the classifications are adapted for the context of particular sport. For example, Roth and Cohen (1986) categorized coping as approach strategies (the athletes` effort to confront the stressor by taking direct action, planning future activities or putting in more effort) and avoidance strategies (the athletes` attempt to avoid a stressful situation). Another classification that is most commonly used in the psychology of sports is the three-factor model (Gaudreau \& Blondin, 2004): task-oriented coping (strategies for mastering stressful situations, i.e., thought control and imagery), 
distraction-oriented coping (strategies for changing the focus to non-sport-related aspects, i.e., distancing oneself from the situation and mental distraction), and disengagementoriented coping (strategies used to abandon a situation and personal goals).

Athletes use various coping strategies (Crocker et al., 2015) and there is evidence of individual differences in responding to competitive stressors and selecting specific coping strategies (Gaudreau \& Blondin 2004). Although it can be argued that certain coping strategies are universally efficient, in literature evidence can be found that task-oriented strategies are better predictors of physical and psychological outcomes, and that distraction-oriented and disengagement-oriented strategies are better predictors of poorer physical and mental outcomes and superior achievement (Connor-Smith \& Flachsbart, 2007). Understanding the choice of appropriate coping strategies as well as the factors that influence them are crucial for improving the competitive achievement (Nicholls, Taylor, Carroll, \& Perry, 2016) and psychological well-being of athletes (Nicholls, Levy, Carson, Thompson, \& Perry, 2016).

The basic dimensions of personality can directly affect the process of coping with stress by having influence over choice of strategies for coping with stress (Bolger \& Zuckerman, 1995; DeLongis \& Holtzman, 2005). In the last couple of decades, a dominant model for assessing basic personality structure is the Five-Factor model (Costa \& McRae, 1985). According to this model, the personality can be assessed across five dimensions (Costa \& McRae, 1985): neuroticism (N) differentiates emotional adjustment and emotional stability from unadjustment and emotional instability; extroversion (E) relates to proneness to sociability, activism and optimism opposed to introversion - negative emotional states and self-consciousness; openness to experience $(\mathrm{O})$ represents aspiration towards new ideas, experiences and values, as opposed to conservatism and preference of the known over the unknown; agreeableness (A) is an interpersonal dimension that is characterized by love and trust towards people, unselfishness and empathy, as opposed to cynicism, selfishness and distrust; conscientiousness (C) is about control of impulses, setting and achieving goals, being organized, following rules and norms, delaying gratification, being strong minded and self-disciplined as opposed to hedonism, carelessness and laziness.

Unlike other areas of psychology outside of the sports context with a considerable number of investigations of the Five-Five factor on dispositional coping strategies, in the psychology of sport there have only been a few studies dedicated to that matter (Kaiseler, Polman, \& Nicholls, 2012; Allen, Greenless, \& Jones, 2013; Keiseler, Levy, Nicholls, \& Madigan, 2017). One study of the relation between the Five-Factor model on coping was conducted on a large sample of athletes who competed at a variety of sports (Kaiseler et al., 2012). The authors have found that high neuroticism is associated with emotion- and avoidance coping strategies and low neuroticism with problem-focused coping strategies; athletes who scored high on extraversion more frequently used problem-oriented strategies; extraversion and neuroticism are positive predictors of disengagement coping; also, high conscientiousness is a positive predictor of problem-focused strategies, and a negative predictor of emotion-coping strategies. Other research studies have applied a typological approach to exploring possible combinations of personality traits with a sample of athletes who competed in different sport disciplines at different levels of success (Allen et al., 2011). The results showed a greater preference of problem-focused coping strategies is associated with high extraversion, emotional stability, and openness to new experiences. Furthermore, frequent use of emotion-focused coping strategies is associated with high conscientiousness, extraversion, openness, and agreeableness. A greater use of avoidance 
coping strategies is connected with lower openness and higher neuroticism. In their recent study, Kaiseler and associates (2017) examined independent and interactive effects of personality traits on dispositional coping in sport. Extraversion, agreeableness, and openness were significant direct predictors of task-oriented strategies. Neuroticism is a positive predictor of distraction-oriented coping, whereas extraversion, agreeableness and conscientiousness are negative ones. Extraversion and neuroticism were positive direct predictors of disengagement-oriented coping strategies, but agreeableness and conscientiousness were negative. In accordance with the results obtained, Allen and associates (2011) reported that there are interactive effects of neuroticism and openness, as well as extraversion and neuroticism in predicting task-oriented coping. Also, the interactive effect of agreeableness and conscientiousness was found in predicting distraction-oriented coping.

Since there is a lack of studies on personality and coping in sport, the main aim of this study was to investigate direct and interactive effects of the Five-Factor factor model on dispositional coping strategies used by young volleyball players. Previous research conducted on a diverse sample included type of sport, age, and competitive level. These studies were not designed to assess this relationship in young athletes who compete in one sport discipline. Practically, it is important to establish the possibility of advising athletes to use coping strategies that are suitable for their personality structure. In addition, the aim of this study was to examine the second order factorial structure of the Serbian version of dispositional coping strategies.

\section{METHOD}

\section{Sample}

The sample consisted of 166 female volleyball athletes from Belgrade, Niš, Kragujevac and Zrenjanin. The mean age was 15.01 years $(S D=.87)$. Mean sport experience was 4.81 years $(S D=1.85)$.

\section{Instruments}

We used the NEO-FFI inventory (Costa \& McRae, 1989) that demonstrates high correlations with analogous scales like the Big Five Questionnaire as to measure up basic personality dimensions (Barbaranelli \& Caprara, 2000, in Costa, Oliva, \& Cuzzocrea, 2014). This scale contains 60 items grouped into five subscales (12 items per each subscale): Neuroticism, Extraversion, Openness to Experience, Agreeableness, and Conscientiousness. The task of the respondent was to mark the degree to which they found every claim to be truthful. The answers for each item are given on a five-point Likert type scale (from $1=$ totally inaccurate, up to $5=$ totally correct). The results are obtained by the sum of answers to all the questions on a corresponding subscale, where a bigger score signifies a greater expression of a given personality trait. 
The Dispositional Coping Inventory for Competitive Sport (DCICS) is a theory-based scale for the assessment of coping strategies used by athletes during a competition (Hurst et al., 2011) which represents a modification of the original Coping Inventory for Competitive Sport Instrument (Gaudreau \& Blondin, 2002). This scale has 39 items grouped within ten subscales (3 items for the Effort expenditure subscale and 4 items for the other subscales): thought control, mental imagery, relaxation, effort expenditure, logical analysis, seeking support, venting of unpleasant emotion, mental distraction, disengagement/resignation, and social withdrawal. The task of the respondents was to mark the degree to which every item represents their usual thoughts and deeds when faced with competitive stress factors. Answers to every item are indicated on a five-point Likert type scale (from $1=$ completely disagree, up to $5=$ completely agree). The results represent an average of answers given on a corresponding subscale, wherein a bigger score signifies a higher frequency of use of a given coping inventory.

\section{Procedure}

The research was conducted at sports clubs whose members were female athletes who train volleyball. Prior to the research, the athletes were informed that the research is of a voluntary and anonymous character and that the results will be used for research purposes. The competition of the questionnaire lasted 20 minutes.

\section{Statistical analysis}

The data were analyzed with descriptive statistics $(M, S D)$. In order to validate the second order factor of the DCICS an explorative factor analysis (Principal component analyses with Oblimin rotation) was performed. The Paired samples t-test was performed to test differences in the frequency of use of task- and emotion-oriented coping strategies. First, a Pearson correlation analysis was applied to test the association between personality dimensions and coping strategies. A hierarchical regression (the enter method) was performed to directly test the interactive effects of Five-Factor personality dimensions on second order dispositional coping strategies. At Step 1 the independent predictor variables were the Five-Factor personality traits (Neuroticism, Extraversion, Openness to Experience, Agreeableness, and Conscientiousness), and the criterion variables were the dimensions of a higher-order factor: task-oriented and emotion-oriented coping strategies. For Step 2, the interaction effects between all Big-Five dimensions were used as predictors and in this step, the predictor variables were mean-centred.

\section{RESULTS}

\section{Descriptive statistics}

Table 1 presents the descriptive statistics for basic personality traits and strategies for coping with competitive stress. The results indicate that the most prominent traits in athletes are conscientiousness, extraversion and agreeableness. When faced with competitive stress, they most often apply thought control and investing effort and least often resort to resignation and social withdrawal. 
Table 1 Descriptive statistics for basic personality traits and stress coping mechanisms

\begin{tabular}{lccccc}
\hline & $\mathrm{N}$ & Min & Max & M & SD \\
\hline Neuroticism & 166 & 17 & 47 & 30.96 & 5.86 \\
Extraversion & 166 & 33 & 58 & 44.73 & 4.23 \\
Openness to Experiences & 166 & 26 & 52 & 37.27 & 4.85 \\
Agreeableness & 166 & 26 & 52 & 42.07 & 4.68 \\
Conscientiousness & 166 & 32 & 59 & 48.86 & 5.04 \\
Thought control & 166 & 2 & 5 & 4.17 & 0.55 \\
Mental imagery & 166 & 1.25 & 5 & 3.62 & 0.75 \\
Relaxation & 166 & 2 & 5 & 3.67 & 0.77 \\
Effort expenditure & 166 & 1.33 & 5 & 4.06 & 0.82 \\
Logical analysis & 166 & 1.5 & 5 & 3.87 & 0.73 \\
Seeking support & 166 & 1 & 5 & 3.58 & 0.79 \\
Venting of unpleasant emotion & 166 & 1 & 4.75 & 2.61 & 0.97 \\
Mental distraction & 166 & 1 & 4.75 & 2.26 & 0.99 \\
Disengagement/resignation & 166 & 1 & 4 & 1.65 & 0.62 \\
Social withdrawal & 166 & 1 & 4 & 1.82 & 0.7 \\
\hline
\end{tabular}

Legend: N=Number of Participants; Min-Minimum; Max-Maximum; M-Mean; SD-Standard Deviation.

\section{Factor analysis}

In order to check the second order factor structure of the questionnaire on our sample of respondents, an exploratory factor analysis was conducted on ten subscales. In accordance with previous research (Amiot, Gaudreau, \& Blanchard, 2004), a Principal component analysis was applied using an oblimin rotation in two steps. The first step indicated a threefactor solution that was not in line with the theoretical assumptions and was not interpretable. In the second step, two factors were a priori fixed. This solution was in line with theoretically established taxonomies of the coping strategies, as well as with the twofactor solution by the author of the instrument, and it was interpretable. Kaiser-MeyerAulkin's measure of adequacy of the sample is .76 which is higher than the recommended value of .60 and Bartlett's test of sphericity is significant $(45)=360.74, p<.01$. These two components explain $50.9 \%$ of the total variance, with the first component explaining $31.7 \%$, and the second component explaining $19.2 \%$ of the variance. Both components contain subscales with saturations significantly higher than .30 . In line with the expectations, the first component, task-oriented coping, contains six different subscales: effort expenditure, logical analysis, relaxation, mental imagery, seeking support and thought control. The second component, emotion-focused coping, contains the following four subscales: disengagement/ resignation, mental distraction, social withdrawal, and venting of unpleasant emotion. Cronbach's alpha coefficients of reliability were good: for the dimension of task-oriented coping (23 items), $\alpha=.87$, and for the dimension of emotion-focused coping (16 items), $\alpha=.84$. A further analysis in this research has been applied in this factor solution. 
Table 2 Factor saturations established on the main components with an oblimin rotation method

\begin{tabular}{lcc}
\hline & \multicolumn{2}{c}{ Saturations } \\
\cline { 2 - 3 } & Factor 1 & Factor 2 \\
\hline Effort expenditure & .849 & \\
Logical analysis & .835 & \\
Relaxation & .738 & \\
Mental imagery & .733 & \\
Seeking support & .678 & \\
Thought control & .403 & .797 \\
Disengagement/resignation & & .736 \\
Mental distraction & & .625 \\
Social withdrawal & & .528 \\
Venting of unpleasant emotion & & \\
\hline
\end{tabular}

\section{Paired samples t-test}

A paired samples t-test has shown that there is a significant statistical difference in frequency of use of task-focused coping and emotion-focused coping when facing competitive stressors, $\mathrm{t}(132)=25.55, \mathrm{p}<.00$. Female athletes resort to task-focused coping strategies significantly more often $(\mathrm{M}=3.56, \mathrm{SD}=57)$.

\section{Correlation analysis}

Table 3 shows the correlation (Pearson's) between basic personality traits and stresscoping strategies. Task-focused coping strategies are in a positive correlation with extraversion and conscientiousness, while emotion-focused coping strategies are in a positive correlation with neuroticism and in a negative correlation with agreeableness, conscientiousness and extroversion.

Table 3 Correlations between personality traits and coping strategies

\begin{tabular}{llllllll}
\hline & $\mathrm{N}$ & $\mathrm{E}$ & $\mathrm{O}$ & $\mathrm{A}$ & $\mathrm{C}$ & $\mathrm{TOC}$ & $\mathrm{EOC}$ \\
\hline Neuroticism & 1.00 & & & & & & \\
Extraversion & $-.39^{* *}$ & 1.00 & & & & & \\
Openness to Experiences & -.10 & .10 & 1.00 & & & & \\
Agreeableness & $-.29^{* *}$ & .03 & .13 & 1.00 & & & \\
Conscientiousness & $-.38^{* *}$ & $.22^{* *}$ & .10 & $.33^{* *}$ & 1.00 & & \\
Task-Oriented Coping & -.04 & $.17^{*}$ & .01 & .04 & $.40^{* *}$ & 1.00 & \\
Emotion-Oriented Coping & $.52^{* *}$ & $-.21^{*}$ & -.11 & $-.45^{* *}$ & $-.31^{* *}$ & -.04 & 1.00 \\
\hline
\end{tabular}

Legend: N-Neuroticism; E-Extraversion; O-Openness to Experiences; A-Agreeableness; C-Conscientiousness; TOC-Task-Oriented Coping; EOC-Emotion-Oriented Coping; ${ }^{*}-p<.05,{ }^{* *}-p<.05 .01$.

\section{Regression analysis}

To determine the predictive validity of personality traits for the choice of coping mechanisms, two multiple hierarchical regression analyses were applied (the enter method) in which the criterion variables were task-related coping, or emotion-related coping (Table 4). In the first block, the predictor variables were personality dimensions, and in the second block, the predictor variables were the interaction of each dimension with another (10 in total). Before the interactions were calculated, the data were centred. The results showed a 
regression function in which the criterion variable task-focused coping had significant prediction power, $\mathrm{R}=.45, \Delta \mathrm{R}^{2}=.20, \mathrm{~F}(5,140)=6.91, \mathrm{p}=.00$, with the only significant predictor being the conscientiousness dimension. Adding interactions between personality dimensions in the second block did not significantly increase the percentage of the explained variance, $\Delta \mathrm{R}^{2}=.07, \mathrm{p}=.26$, total $\mathrm{R}=.52, \Delta \mathrm{R}^{2}=.27, \mathrm{~F}(15,130)=3.20, \mathrm{p}=.00$. The regression function in which the criterion variable is emotion-focused coping also had significant prediction power, $\mathrm{R}=.63, \Delta \mathrm{R}^{2}=.47, \mathrm{~F}(5,141)=18.57, \mathrm{p}<.05$, and the significant predictors were Neuroticism and Agreeableness, which are negatively correlated. Adding interactions between personality dimensions in the second block again did not increase the percentage of the variance explained, $\Delta \mathrm{R}^{2}=.07, \mathrm{p}=.08$, total $\mathrm{R}=.68, \Delta \mathrm{R}^{2}=.54, \mathrm{~F}(15,131)=7.66, \mathrm{p}=.00$.

Table 4 Hierarchical multiple regression analysis: prediction of coping strategies based on basic personality dimensions and their interactions

\begin{tabular}{|c|c|c|c|c|c|c|c|c|}
\hline & \multicolumn{5}{|c|}{$\mathrm{TOC}$} & \multicolumn{3}{|c|}{$\mathrm{EOC}$} \\
\hline & $\Delta \mathrm{R}^{2}$ & $\beta$ & $\mathrm{t}$ & $\mathrm{p}$ & $\Delta \mathrm{R}^{2}$ & $\beta$ & $\mathrm{t}$ & $\mathrm{p}$ \\
\hline Block 1 & \multirow[t]{6}{*}{.20} & & & & \multirow[t]{6}{*}{.47} & & & \\
\hline Neuroticism & & .16 & 1.81 & .07 & & .44 & 5.79 & .00 \\
\hline Extraversion & & .12 & 1.44 & .15 & & .01 & 0.12 & .91 \\
\hline Openness to Experiences & & .09 & 1.12 & .27 & & -.05 & -0.74 & .46 \\
\hline Agreeableness & & -.07 & -0.86 & .39 & & -.34 & -4.93 & .00 \\
\hline Conscientiousness & & .44 & 5.31 & .00 & & -.02 & -0.26 & .79 \\
\hline Block 2 & \multirow[t]{16}{*}{.07} & & & & \multirow[t]{16}{*}{.07} & & & \\
\hline Neuroticism & & .16 & 1.65 & .1 & & .45 & 5.74 & .00 \\
\hline Extraversion & & .15 & 1.70 & .09 & & .02 & 0.25 & .80 \\
\hline Openness to Experiences & & .09 & 1.07 & .29 & & -.03 & -0.37 & .71 \\
\hline Agreeableness & & -.1 & -1.25 & .21 & & -.37 & -5.04 & .00 \\
\hline Conscientiousness & & .45 & 5.13 & .00 & & -.06 & -0.75 & .45 \\
\hline $\mathrm{NxE}$ & & -.01 & -0.09 & .93 & & .12 & 1.45 & .15 \\
\hline $\mathrm{NxO}$ & & -.01 & -0.11 & .91 & & .08 & 0.88 & .38 \\
\hline $\mathrm{NxA}$ & & -.05 & -0.54 & .59 & & .13 & 1.56 & .12 \\
\hline $\mathrm{NxC}$ & & .09 & 1.05 & .30 & & -.13 & -1.68 & .09 \\
\hline $\mathrm{ExO}$ & & .12 & 1.15 & .25 & & -.09 & -1.01 & .31 \\
\hline ExA & & -.02 & -0.27 & .79 & & .05 & 0.67 & .51 \\
\hline $\mathrm{ExC}$ & & -.04 & -0.38 & .71 & & -.06 & -0.75 & .45 \\
\hline OxA & & -.01 & -0.06 & .95 & & -.02 & -0.24 & .81 \\
\hline $\mathrm{OxC}$ & & -.18 & -2.07 & .04 & & .21 & 2.42 & .02 \\
\hline $\mathrm{AxC}$ & & .16 & 1.72 & .09 & & .16 & 1.96 & .05 \\
\hline Total & .27 & & & & .54 & & & \\
\hline
\end{tabular}

Legend: TOC-Task Oriented Coping; EOC-Emotion Oriented Coping; NxE-Neuroticism x Extraversion;

NxO-Neuroticism x Openness to Experiences; NxA-Neuroticism x Agreeableness; NxC-Neuroticism x

Conscientiousness; ExO-Extraversion x Openness to Experiences; ExA-Extraversion x Agreeableness; ExC-Extraversion x Conscientiousness; OxA-Openness to Experiences x Agreeableness;

OxC-Openness to Experiences x Conscientiousness; AxC-Agreeableness x Conscientiousness.

\section{DISCUSSION}

Having in mind that athletic competition abounds in stressors, choosing the appropriate coping strategies is important for better competitive achievement as well for the psychological well-being of athletes. The main goal of this research was to investigate the 
direct and interactive effects of the Five-Factor model on dispositional coping strategies of young volleyball players. In addition, we wanted to verify the second-order factor structure of the DCICS instrument. According to some theoretical stance, regardless of the fact whether we estimate a process or a disposition, ten subscales of strategies for coping with competitive stress of this instrument can be grouped into second-order dimensions. In their initial work, the authors of the instrument (the version intended to estimate the process) argued that the results of the confirmatory factor analysis did not provide bases for drawing a final conclusion whether a two or three-factor solution is more adequate (Gaudreau \& Blondin, 2002). In the same article the authors presented the assumption that the factor structure of the instrument can depend on the characteristics of a sample and it is necessary to have this checked with different samples of participants (including athletes that train different sports disciplines, as well as athletes with different levels of competitive success). In some of the research that followed, a three-factor solution was applied and/or confirmed (Gaudreau, El Ali, \& Marivain, 2005; Nichols, Polman, Levy, \& Blackhouse, 2008), but in other studies a two-factor solution was used (Amiot et al., 2004; Hajji, Baaziz, Mnedla, Jannet, \& Elloumi, 2016). The results of our research have provided a two-factor solution with a high reliability coefficient. The first factor is task-oriented strategies (actions for changing or mastering some aspects of a situation), and second, emotion-oriented strategies (actions for changing the interpretation of a stressful situation and regulating negative emotions) which integrated items from distraction-oriented coping and disengagementoriented coping subscales.

Female athletes in our research apply task-oriented strategies significantly more often (activities intended at changing situations during competition), which are considered better predictors of physical mental outcomes and achievement (Connor-Smith \& Flachsbart, 2007) than emotions-oriented coping strategies.

In the current study, neuroticism, extraversion, agreeableness, and conscientiousness are in relation with task- or emotions-oriented strategies, but associations between openness and coping strategies were not found. A correlational analysis revealed that extraversion and conscientiousness were associated with using task-oriented coping strategies. Although extraversion is in a positive correlation with task-oriented coping, conscientiousness is only one significant predictor of using task-oriented coping strategies. These results are not in line with previous results in the domain of sport (Allen et al., 2011; Kaiseler et al., 2012). Namely, previous authors reported that extraversion is a positive predictor of task-oriented coping. Practically, athletes in the current research who are high on conscientiousness, i.e., desire to do a task well, tend to be goal-oriented, efficient, and well organized, show self-discipline and rather display planned than spontaneous behaviour, trying to take control over stressful situations, and choose strategies like expenditure, logical analysis, mental imagery, etc. The correlational analysis revealed a tendency for neuroticism to be in a positive and conscientiousness, agreeableness and extraversion in a negative association with use emotionoriented coping strategies. Regression coefficients showed that neuroticism was positive, and agreeableness was a negative predictor of emotional-oriented coping strategies. That would mean that athletes who are high on neuroticism (emotionally unstable, anxious, hostile, and vulnerable) or low on agreeableness (these who are cynical, rude, and uncooperative) more likely choose coping directed at changing the interpretation of a stressful situation and to managing negative emotions rather than changing the situation. The result that athletes who have tendencies to be less emotionally stable (high on neuroticism) is in line with previous research (Allen et al., 2011; Kaiseler et al., 2012; Kaiseler et al., 2017) that athletes who are 
high on neuroticism tend to use more distraction- and disengagement-oriented coping (the scales that were integrated in our research). The result obtained in this research, that agreeableness is a negative predictor of emotional-oriented strategies, is not in compliance with previous studies in the context of sport (Kaiseler et al., 2012; Kaiseler et al., 2017) that showed that this dimension independently or in interaction with other personality dimension is a predictor of task-oriented coping.

A possible explanation for somewhat different results obtained in this study compared to the results of previous research would be that in the previous research the samples were heterogeneous considering the type of sport (including different individual and team sports), age, sport experience and competitive achievements. In the present study the sample consisted of young volleyball players. Volleyball is a sport that requires a high level of player cooperation and a uniqueness of volleyball is manifested in the rules of winning points. According to the rules, when a player misses or does not score a point (that is not the case in other team sports), the point goes to the opponent. Any change in points may be potentially stressful. Thus, for example, athletes who are low on agreeableness, and who are less trustful, cooperative, and compliant tend to use more actions that are implemented to reframing a stressful situation and to regulating negative emotions.

Because of the general lack of research findings exploring the interaction effects of the Five-Factor personality traits on dispositional coping in the context of sport, it is not possible to formulate any firm empirically based hypotheses as to why no interactive effects were found in the present study.

\section{CONCLUSION}

This study is the second one in the context of sport and it is aimed at exploring the relationship between the Five-Factor personality dimensions and coping at the dispositional level. Such findings confirm the assumption that there are connections between basic personality dimensions and dispositional coping in the context of sport competition. The second aim of this study was to examine the second order factorial structure of the Serbian version of dispositional coping strategies. The obtained results indicated that it is valid to assess two high order factor structures: task-oriented coping and emotion-oriented coping in the volleyball.

Potentially, such results can have a practical value and can encourage coaches and applied sport psychologists to urge those athletes who are high on neuroticism and/or low on agreeableness to more frequently choose task-oriented coping strategies and to prevent them from using coping strategies that are not in accordance with their personality dimensions.

The findings of this study have some limitations that give directions for future research. The main limitation of this study refers to the sample size, which is relatively small and not sufficient for application of a confirmatory factor analysis. Future research could explore these relationships including the potentially moderating effect of social-demographic variables, i.e., gender differences, different sport experience, competitive achievement, and differences between team sports. From a practical point, it would be valuable to examine the effect of the intentions to train and encourage athletes, especially those with high neurotic or low agreeableness, to use more task-oriented coping strategies. 
Acknowledgement: The research reported in this paper was funded by the Ministry of Education and Science and Technological Development of the Republic of Serbia - Project "Effects of applied physical activity on locomotion, metabolic, psycho-social and educational status of the population in Republic of Serbia" (No. III47015).

\section{REFERENCES}

Abedalhafiz, A. Altahayneh, Z., \& Al-Haliq, M. (2010). Sources of stress and coping styles among studentathletes in Jordan universities. Procedia Social and Behavioral Sciences, 5, 1911-1917.

Allen, M.S., Greenlees, I., \& Jones, M. (2011). An investigation of the five-factor model of personality and coping behaviour in sport, Journal of Sports Sciences, 29(8), 841-850.

Amiot, C.E., Gaudreau, P., \& Blanchard, C.M. (2004). Self-determination, coping, and goal attainment in sport. Journal of Sport and Exercise Psychology, 26(3), 396-411.

Barbaranelli, C., \& Caprara, G.V. (2000). Measuring the Big Five in Self Report and Other Ratings: a multitraitmultimethod study. European Journal of Psychological Assessment, 16(1), 29-41.

Bolger, N., \& Zuckerman, A. (1995). A framework for studying personality in the stress process. Journal of Personality and Social Psychology, 69(5), 890-902.

Compas, B.E., Connor-Smith, J.K., Saltzman, H., Thomsen, H.A., \& Wadsworth, M.E. (2001). Coping with stress during childhood and adolescence: Progress, problems, and potential in theory and research. Psychological Bulletin, 127(1), 87-127.

Connor-Smith, J. K., \& Flachsbart, C. (2007). Relations between personality and coping: a meta-analysis. Journal of Personality and Social Psychology, 93(6), 1080.

Costa, P.T., \& McCrae, R.R. (1985). The NEO Personality Inventory manual. Odessa. FL: Psychological Assessment Resources

Costa, P.T.Jr., \& McCrae, R.R. (1989). NEO PI/FFI manual supplement for use with the NEO Personality Inventory and the NEO Five-Factor Inventory. Psychological Assessment Resources.

Costa, S., Oliva, P., \& Cuzzocrea, F. (2014). Motivational aspects and personality correlates of physical exercise behavior. Facta Universitatis Series Physical Education and Sport, 12(2), 83-93.

Crocker, P.R.E., \& Graham, T.R. (1995). Coping with competitive athletes with performance stress: Gender differences and relationships with affect. The Sport Psychologist, 9(3), 325-338.

Crocker, P.R.E., Tamminen, K.A., \& Gaudreau, P. (2015). Coping in sport. In S. Hanton \& S. Mellalieu (Eds.), Contemporary advances in sport psychology: a review, (pp. 28-67). New York: Routledge.

DeLongis, A., \& Holtzman, S. (2005). Coping in context: The role of stress, social support, and personality in coping. Journal of Personality, 73(6), 1633-1656.

Fletcher, D., Hanton, S., \& Mellalieu, S.D. (2006). An organisational stress review: Conceptual and theoretical issues in competitive sport. In S. Hanton \& S.D. Mellalieu (Eds.), Literature reviews in sport psychology. New York: Nova Science Odessa, FL: Psychological Assessment Resources.

Gaudreau, P., \& Blondin, J.P. (2002). Development of a questionnaire for the assessment of coping strategies employed by athletes in competitive sport settings. Psychology of Sport and Exercise, 3(1), 1-34.

Gaudreau, P., \& Blondin, J.P. (2004). Different athletes cope differently during a sport competition: a cluster analysis of coping. Personality and Individual Differences, 36(8), 1865-1877.

Gaudreau, P., El Ali, M., \& Marivain, T. (2005). Factor structure of the Coping Inventory for Competitive Sport with a sample of participants at the 2001 New York marathon. Psychology of Sport and Exercise, 6(3), 271-288.

Hajji, J., Baaziz, M., Mnedla, S., Jannet, Z.B., \& Elloumi, A. (2016). Validation of the Arabic Version of the Inventory of Coping Strategies of Competitive Sport (ISCCS). Advances in Physical Education, 6(4), 312.

Hurst, J.R., Thompson, A., Visek, A.J., Fisher, B., \& Gaudreau, P. (2011). Towards a dispositional version of the coping inventory for competitive sport. International Journal of Sport Psychology, 42(2), 167-185.

Kaiseler, M., Polman, R.C., \& Nicholls, A.R. (2012). Effects of the Big Five personality dimensions on appraisal coping, and coping effectiveness in sport. European Journal of Sport Science, 12(1), 62-72.

Kaiseler, M., Levy, A., Nicholls, A.R., \& Madigan, D.J. (2017). The independent and interactive effects of the Big-Five personality dimensions upon dispositional coping and coping effectiveness in sport. International Journal of Sport and Exercise Psychology, 17(4), 410-426.

Kimball, A., \& Freysinger, V. J. (2003). Leisure, stress, and coping: The sport participation of collegiate studentathletes. Leisure Sciences, 25(2-3), 115-141. 
Kowalski, K.C., \& Crocker, P.R. (2001). Development and validation of the Coping Function Questionnaire for adolescents in sport. Journal of Sport and Exercise Psychology, 23(2), 136-155.

Louvet, B., Gaudreau, P., Menaut, A., Genty, J., \& Deneuve, P. (2007). Longitudinal patterns of stability and change in coping across three competitions: a latent class growth analysis. Journal of Sport and Exercise Psychology, 29(1), 100-117.

Nicholls, A.R., Levy, A.R., Carson, F., Thompson, M.A., \& Perry, J.L. (2016). The applicability of self-regulation theories in sport: Goal adjustment capacities, stress appraisals, coping, and well-being among athletes. Psychology of Sport and Exercise, 27, 47-55.

Nicholls, A.R., Taylor, N.J., Carroll, S., \& Perry, J.L. (2016). The development of a new sport specific classification of coping and a meta-analysis of the relationship between different coping strategies and moderators on sporting outcomes. Frontiers in Psychology, 7, 1674, https://doi.org/10.3389/fpsyg.2016.01674

Nicholls, A.R., \& Polman, R.C. (2007). Coping in sport: a systematic review. Journal of Sports Sciences, 25(1), 11-31.

Nicholls, A.R., Polman, R.C., Levy, A.R., \& Backhouse, S.H. (2008). Mental toughness, optimism, pessimism, and coping among athletes. Personality and Individual Differences, 44(5), 1182-1192.

Skinner, E.A., \& Zimmer-Gembeck, M.J. (2007). The development of coping. Annual Review of Psychology, 58, 119-144.

Roth, S., \& Cohen, L.J. (1986). Approach, avoidance, and coping with stress. American Psychologist, 41(7), 813-819.

\section{ODNOS IZMEĐU OSNOVNIH DIMENZIJA LIČNOSTI I DISPOZICIONIH STRATEGIJA SUOČAVANJA SA STRESOM U ODBOJCI}

Strategije suočavanja sa stresom koje koriste sportisti smatraju se značajanim faktorom koji doprinosi takmičarskom postignuću, kao i psihološkoj dobrobiti sportista. Ciljevi ovog rada bili su da se ispitaju direktni uticaji i efekti interakcije Big Five dimenzija ličnosti na dispozicione dimenzije suočavanja sa stresom drugog reda $i$ da se testira faktorotska struktura drugog reda Inventara dispozicionih strategija suočavanja sa stresom. Uzorak je činilo 166 odbojkašica prosečnog uzrasta 15.01 godina $(S D=.87)$ i prosečnog sportskog staža 4.81 godina $(S D=1.85)$. Ispitanice su popunile NEO-FFI inventar i inventar za procenu dispozicionih strategija suočavanja sa takmičarskim stresomDCICS. Eksplorativnom faktorskom analizom je dobijeno dvofaktorsko rešenje drugog reda sa visokim koeficijentima pouzdanosti: suočavanje usmereno na zadatak $i$ suočavanje usmereno na emocije. Regresiona analiza je pokazala da su neke od BigFive dimenzija ličnosti nezavisni prediktori stategija suočavanja višeg reda. Savesnost je pozitivan prediktor strategija usmerenih na zadatak. Neuroticizam je pozitivan, a saradljivost negativan prediktor strategija suočavanja usmerenog na emocije. Nijedna od interakcija BigFive dimezija ličnosti nije značajan prediktor dispozicionih dimenzija. Dobijeni nalazi ukazuju na to da petofaktorski model ličnosti može da bude od koristi u identifikovanju stretegija suočavanja koje sportsiti primenjuju. Takođe, nalazi ističu potrebu ka dodatnim istraživanjima namenjenim ispitivanju ovog složenog odnosa uključujući i moguće delovanje moderatosrskih varijabli kao što su pol, takmičarsko iskustvo i različite sporske discipline.

Ključne reči: crte ličnosti, strageije suočavanja, sportisti 